
March 1943

\title{
OCCURRENCE OF SUCROSE AND INULIN-HYDROLYZING ENZYMES IN COMMERCIAL ENZYME PREPARATIONS
}

\author{
By William Ward Pigman
}

\begin{abstract}
The relative enzyme content of enzyme preparations which hydrolyze sucrose and inulin was determined for 14 enzyme preparations representing the principal commercial types available. Those of fungal origin seem invariably to contain invertases in about 0.5 to 1.0 percent of the quantities in commercial purified yeast invertase preparations. Enzyme preparations from plant sources (wheat, almond, and malt), from animal tissues (pancreases), and from Bacillus mesentericus had negligible contents of invertase. Enzyme preparations from Aspergillus niger and yeast exhibited considerable ability to hydrolyze inulin, those from Aspergillus oryzae and A. flavus exhibited some slight activity, and preparations from other sources were essentially inactive. For several representative enzyme preparations, the rate of hydrolysis of inulin and sucrose was studied and found to approximate a first-order reaction. The activity of the inulase in several $A$. niger enzyme preparations was found to be greatest in the range $\mathrm{pH} 3$ to 4 . Invertase preparations from $A$. niger were most active at $\mathrm{pH} 3$ to 4 and those from A. oryzae at $\mathrm{pH} 5.0$ to 5.5 .

The results are considered from the viewpoint of the Weidenhagen theory, and it is shown that the original theory is incompatible with the present results in that either the invertases and inulases are different enzymes or they represent a class of enzymes (fructofuranosidases) in which the individual members vary according to the source. Thus the ratio of invertase to inulase activity varies from about 5 for the $A$. niger preparations to more than 4,000 for the yeast preparation. Following the suggestion of Helferich, the term "emulsin" is used as a synonym for a crude mixture of enzymes.

It is shown that the $A$. niger emulsins hydrolyze juices from the jerusalem artichoke, which contain levulose polysaccharides. This reaction may be useful for the commercial production of levulose from this source, as enzymic hydrolysis has certain advantages that may off set the high cost of the enzyme preparation.

Consideration is given to the different methods available for expressing enzyme activity. It is shown, for the enzymes reported in the present paper, that the pseudo first-order reaction constant is proportional to the enzyme concentration over a fairly wide range, and that this constant may be utilized for the expression of the enzyme content of various emulsins. Since the substrate concentration must be specified, it is suggested that the concentrations proposed by Weidenhagen be generally accepted, and that his standard conditions of temperature, etc., also be adopted.
\end{abstract}

\section{CONTENTS}

I. Introduction

II. Expression of enzyme activity

1. Standard conditions

2. Methods for expressing activity

III. Invertase content of enzyme preparations

IV. Inulase content of enzyme preparations

V. Action of inulase on extracts from jerusalem artichokes

VI. Comparison of inulase and invertase activity .... 170 
VII. Experimental procedure

1. Enzyme preparations (emulsins)

(a) Emulsins from plant extracts

(b) Emulsins from animal organs . . . . .

(c) Emulsins from microorganisms . . . . . . . . . .

2. Substrates

3. Buffer solutions

4. Hydrolysis measurements

\section{INTRODUCTION}

For more than a century it has been known that many materials of biological origin contain catalysts for hydrolytic and oxidative reactions. These biological catalysts, or enzymes, should be of considerable commercial interest because of the mild conditions of temperature, pressure, and acidity under which many of them have their optimal activity. They have found limited application in industrial practice, ${ }^{1}$ but their widespread use has been retarded by the lack of knowledge of the many problems involved. Some of the more important problems that have not received systematic study are the distribution of enzymes in natural products, sources of high activity, and the identity or nonidentity of enzymes from different sources which catalyze the same reactions. The present investigation attempts to provide this information for two enzymes, invertase and inulase.

Convenient and important sources of enzymes are the enzyme preparations manufactured for industrial and scientific purposes. These "emulsins" 2 are mixtures of enzymes of various types and are obtained from plant seeds, animal organs, and microorganisms. Some of the well-known products of these types are Malt diastase, Pancreatin, Takadiastase, yeast invertase. Pectinol, Polidase, and Mylase. These and other semicommercial and experimental preparations were studied in the present investigation for their invertase and inulase content.

The use of these enzyme preparations for the present work involved a number of uncertainties, arising particularly from the lack of information of their origin and manufacture, and the results obtained can be considered only as representative of the types of preparations available. The active content of enzyme preparations may be expected to vary from time to time for the same product unless the activity has been standardized by the manufacturer. Where the development of a particular use makes it desirable, it is probable in many instances that the activity may be increased as much as 10 to 100 times by controlling conditions and choosing active strains of microorganisms. It is believed that these difficulties are balanced by the ready availability of the products. Also, in most cases, the main variable is the particular strain of microorganism employed, which frequently is difficult for other investigators to obtain. The

\footnotetext{
1 R. A. Gale, Wallerstein Lab. Comm. 4, 112 (1941); L. Wallerstein, Ind. Eng. Chem. 31, 1218 (1939).

? Helferich has been using the term "emulsin" to mean a mixture of glycosidic hydrolyzing enzymes obtained by the partial purification of plant extracts. Coffee emulsin is a mixture of enzymes obtained from the coffee bean, and yeast emulsin is synonymous with crude-yeast invertase. See B. Helferich and F. Vorsatz, Z. physiol. Chem. 237, 254 (1935). To some writers the term "emulsin" has meant almond emulsin or even the $\beta$-glucosidase therein, but Helferich's usage would seem to be preferable. In the present paper, however, the term "emulsin" is broadened further to include all mixtures of enzymes and is synonymous with "crude or partially purified mixtures of enzymes." It might be noted that a dictionary definition of "emulsin" is "an enzyme preparation obtained from certain fungi and several of the higher plants, notably almonds, and prepared as a white amorphous mass." See Webster's New International Dictionary, second edition (G. and C. Merriam Co., Springfield, Mass., 1939).
} 
information available about the various enzyme preparations is given in section VII, p. 171.

The inulase content was investigated because of the interest of the National Bureau of Standards in the production of levulose from polysaccharides of the inulin type contained in Jerusalem artichoke and dahlia tubers and a number of other plants. ${ }^{3}$

The invertase content was studied to determine the possibility of a correlation with the inulase activity as demanded by the original Weidenhagen theory.

One of the outstanding characteristics of enzymes is the specific nature of their catalytic actions. Very slight changes in the subtrate molecule often suppress the cataly tic action considerably or even completely. This property is of considerable interest for the analysis of plant materials, which are often complex mixtures. The wellknown method for the determination of raffinose in the presence of sucrose ${ }^{4}$ depends on the selective actions of $\alpha$-galactosidase and invertase. Other methods utilizing the procedure of Bourquelot ${ }^{5}$ should be feasible for determining the composition of mixtures such as those containing starch, hemicelluloses, etc. However, as a preliminary requisite for analyses of this type, the occurrence of the necessary enzymes must be established, and a knowledge of the other enzymes in the same emulsins must be obtained. The present investigation is a start in this direction, and provides data for developing selective methods for the analysis of mixtures of inulin and sucrose and possibly of other polysaccharides.

\section{EXPRESSION OF ENZYME ACTIVITY}

\section{STANDARD CONDITIONS}

Since many methods have been suggested for the determination of enzyme activity, particularly invertase activity, ${ }^{6}$ the choice of any one method is arbitrary. One of the greatest sources of difficulty in the comparison of different methods is that different conditions of substrate concentration, temperature, $\mathrm{pH}$, etc. are specified by the various investigators. Weidenhagen has specified ${ }^{7}$ a set of standard conditions ("Normalbedingungen"), which, because of their widespread applicability, it seems desirable to adopt until more favorable conditions have been found. The exact conditions are given in the following quotation, which is cited here in the original language to avoid any possibility of mistranslation.

"Man löst $2.500 \mathrm{~g}$. Maltose oder die äquivalente Menge eines anderen Substrates bei optimalem $\mathrm{pH}$ und $30^{\circ} \mathrm{C}$ unter Zusatz des entsprechenden Enzyms in $50 \mathrm{~cm}^{3}$ Gesamtvolumen und ermittelt in zu bestimmten Zeiten genommenen Proben den Grad der Hydrolyse."

The standard substrates to be used for several important enzymes are given as maltose ( $\alpha$-glucosidase), salicin ( $\beta$-glucosidase), melibiose $(\alpha$-galactosidase), lactose ( $\beta$-galactosidase), and sucrose (invertase),

\footnotetext{
${ }_{3}$ R. F. Jackson, C. G. Silsbee, and M. J. Proffitt, BS Sci. Pap. 20, 587 (1926) S519; Facts about Sugar 21, 326 (1926); F. J. Bates, Sugar 28, 167 (1926); NBS Letter Circular LC 500 (1937); M. J. Proffitt, J. A. Bogan, and R. F. Jackson, J. Research NBs 19, 263 (1937) RP1025; R. F. Jackson and J. A. Mathews, J. Research NBS 15, 341 (1935) RP832.

C. S. Hudson and T. S. Harding, J. Am. Chem. Soc. 37, 2193 (1915); H. S. Paine and R. T. Balch, J. Ind. Eng. Chem. 17, 240 (1925), J. Am. Chem. Soc. 49, 1019 (1927).

See review by Béguin, Pharm. Acta Helv. 1, 65, 90 (1926).

6 See review by C. A. Browne and F. W. Zerban, Sugar Analysis, p. 434 (John Wiley \& Sons, Inc., New York, N. Y., 1941).

7 Nord-Weidenhagen, Handbuch der Enzymologie, p. 538 (Akademische Verlagsgesellschaft, Leipzig, 1940).
} 
all as indicated above to be at a concentration of $0.1388 M$ in the reaction mixture, at the optimal $\mathrm{pH}$ and at a temperature of $30^{\circ} \mathrm{C}$. For inulin, the suggested concentration is $1.125 \mathrm{~g}$ of anhydrous inulin in $50 \mathrm{ml}$ of solution. The standard concentration applies only to substances of known structure and molecular weight, and for inulin and other polysaccharides, arbitrary concentrations must be employed.

In addition to the conditions specified by Weidenhagen, several other variables need to be controlled. It is well known that both the nature of the buffer and its concentration affect the rate of enzyme reactions. ${ }^{8}$ Acetate and phosphate buffers have been used more extensively for this purpose, and it is now suggested that the solution in which the hydrolysis takes place be $0.160 M$ in acetate buffer or $0.04 M$ in phosphate buffer. These concentrations are easily obtained by diluting four volumes of Walpole $0.2 M$ acetate buffers with one volume of water (or enzyme solution) or by diluting the Clark and Lubs phosphate buffers $(0.05 M)$ in the same proportion. It is also suggested that, when possible, sugar determinations by chemical methods be employed to follow the reactions rather than polariscopic methods, since, under the standard conditions, the rotational changes are rather small for the disaccharides.

In his extensive study of the effects of the structures of glycosides on the rate of enzymic hydrolysis, Helferich has adopted a substrate concentration of $0.052 M$, but the other conditions are the same as those used by Weidenhagen. In specificity studies, and in those instances where the rarity of the substrates or other factors make it desirable to use lower concentrations of substrates than $0.1388 \mathrm{M}$, it is suggested that $0.052 M$ be adopted. However, when the enzymic activities are being measured, the more concentrated solutions should be used.

\section{METHODS FOR EXPRESSING ACTIVITY}

For the expression of enzyme activity, the situation is confused. Most methods depend on the assumption that the hydrolysis of the substrate (e. g., of sucrose by invertase) follows the first-order equation, but since the reaction constant calculated in this manner is affected greatly by the initial concentration of the substrate, the substrate concentration must be fixed arbitrarily. The assumption that a monomolecular " $\mathrm{k}$ " may be calculated is disputed by some investigators, ${ }^{9}$ but since no satisfactory method for general use has been developed without this assumption, no alternative remains at present. ${ }^{10}$

As shown in table 1, the hydrolysis of inulin and sucrose by fungal enzymes appears to follow the first-order equation within a deviation of \pm 10 percent from the average. Most earlier measurements seem to fall within this range, and it is the opinion of the writer that additional careful investigation is necessary before this point can be considered as settled. It seems possible that by choice of a suitable

\footnotetext{
${ }^{8}$ W. A. Wisansky, J. Am. Chem. Soc. 61, 3330 (1939); S. Veibel and H. Lillelund, Enzymologia 9, 161 $(1940)$.

OW. R. Johnston, S. Redfern, and G. E. Miller, Ind. Eng. Chem., Anal. Ed. 7, 82 (1935).

10 Several excellent discussions of enzyme kinetics in relation to methods for the measurement of the ac tivity of enzymes are given by O. Bodansky, J. Biol. Chem. 120,555 (1937), and by D. D. Van Slyke, Advances in Enzymology, p. 33 (Interscience Publishers, New York, N. Y., 1942). An alternative method of expressing activity might be developed by chocsing substrate concentrations high enough that the hydrolysis would be of zero order, i. e., the velocity of hydrolysis would be independent of the substrate concen. tration for a considerable part of the reaction. The low solubility of some of the sugars and derivatives Would limit the general application of this method, and in any case the Weidenhagen substrate concentrations are too dilute for the method to be applied.
} 
substrate concentration, conditions may be found for many enzymes so that the reaction may be expressed by the first-order equation, although it should be noted that the reaction is not of the first order, since it is not independent of the substrate concentration.

For the present investigation, the assumption is made that for a fixed initial substrate concentration, the hydrolytic reaction follows the first-order equation (really the "die away" equation, see footnote 10 ), and the reaction constant may be used as a measure of the activity. Since measurements at the beginning of the reaction are probably less accurate than those at later times, and to minimize the inhibiting effects of products of the hydrolysis, the activity measure-

TABLE 1.-Kinetics of hydrolysis of inulin and sucrose by fungal enzymes

\begin{tabular}{l|l||c|c|c|}
\hline \hline Time & Hydrolysis & $k \times 10^{4}$ & Time & Hydrolysis $\mid k \times 10^{4}$ \\
\hline
\end{tabular}

\section{INULIN}

$T=30.0^{\circ}$ or $50.0^{\circ} \mathrm{C} ; \mathrm{pH}=4.1$; acetate-ion concentration $=0.2 \mathrm{M} ; 1.013 \mathrm{~g}$ of anhydrous inulin in $50 \mathrm{ml}$ of reaction mixture

\begin{tabular}{|c|c|c|c|c|c|}
\hline \multicolumn{3}{|c|}{$\begin{array}{l}\text { A. oryzae emulsin No. } 1 \\
\left(T=30.0^{\circ} \mathrm{C} ; g=0.251 \mathrm{~g}\right)\end{array}$} & \multicolumn{3}{|c|}{$\begin{array}{l}\text { A. niger emulsin No. } 1 \\
\left(T=30.0^{\circ} \mathrm{C} ; g=0.218 \mathrm{~g}\right)\end{array}$} \\
\hline $\begin{array}{l}\quad \text { Min. } \\
134 \\
210 \\
310 \\
618 \\
676 \\
1,440 \\
3 \text { days }\end{array}$ & $\begin{array}{r}\text { Percent } \\
10.4 \\
17.1 \\
25.6 \\
37.6 \\
46.6 \\
55.2 \\
78.9 \\
99.2\end{array}$ & $\begin{array}{l}\text { a }(3.6) \\
\text { a }(3.9) \\
4.1 \\
4.1 \\
4.4 \\
\quad 4.5 \\
4.7\end{array}$ & $\begin{array}{l}\text { Min. } \\
100 \\
160 \\
240 \\
310 \\
390 \\
600 \\
1,455\end{array}$ & $\begin{array}{r}\text { Percent } \\
24.0 \\
37.3 \\
51.6 \\
61.3 \\
70.7 \\
84.9 \\
98.2\end{array}$ & $\begin{array}{r}11.9 \\
12.7 \\
13.1 \\
13.3 \\
13.7 \\
\times(13.7) \\
\end{array}$ \\
\hline Avg. & & 4.4 & & & 12.9 \\
\hline \multicolumn{3}{|c|}{$\begin{array}{l}\text { A. oryzae emulsin No. } 1 \\
\left(T=50.0^{\circ} \mathrm{C} ; g=0.251 \mathrm{~g}\right)\end{array}$} & \multicolumn{3}{|c|}{$\begin{array}{l}\text { A. niger emulsin No. } 2 \\
\left(T=30.0^{\circ} \mathrm{C} ; g=0.256 \mathrm{~g}\right)\end{array}$} \\
\hline $\begin{array}{l}40 \\
70 \\
130 \\
200 \\
290 \\
365\end{array}$ & $\begin{array}{r}7.8 \\
14.4 \\
26.3 \\
38.9 \\
53.0 \\
61.1\end{array}$ & $\begin{array}{l}\text { a }(8.8) \\
\text { a }(9.6) \\
10.2 \\
10.7 \\
11.3 \\
11.2\end{array}$ & $\begin{array}{l}100 \\
240 \\
380 \\
605 \\
1,440 \\
1,820\end{array}$ & $\begin{array}{r}5.3 \\
13.8 \\
21.8 \\
32.0 \\
64.4 \\
72.9\end{array}$ & $\begin{array}{c}3(2.7) \\
2.8 \\
2.8 \\
3.1 \\
3.1\end{array}$ \\
\hline \multirow{2}{*}{$\mathrm{Avg}_{\ldots}$} & & 10.8 & & & \\
\hline & & & & & 3.0 \\
\hline
\end{tabular}

SUCROSE

Sucrose concentration: $2.375 \mathrm{~g}$ in $50 \mathrm{ml}$ of reaction mixture; $\mathrm{pH}=4.5$ (acetate-ion concentration $=0.16 \mathrm{M}$ )

A. niger emulsin No. 1

$\left(T=30.0^{\circ} \mathrm{C} ; g=0.0438 \mathrm{~g}\right)$

\begin{tabular}{r|r|r}
\hline 70.4 & 8.6 & a $(13.0)$ \\
130 & 19.2 & a $(13.2)$ \\
190 & 32.7 & 13.2 \\
250 & 43.7 & 13.1 \\
390.5 & 53.6 & 13.3 \\
$26 \mathrm{hr}$ & 63.3 & 13.6 \\
& 70.8 & 13.4 \\
\hline
\end{tabular}

a The values in parentheses were not considered in obtaining the average values. 


\section{Journal of Research of the National Bureau of Standards}

ments were carried out in the interval 30- to 50-percent hydrolysis in most instances. By limiting this interval still more, it should be possible to minimize the effects of deviations from the first-order equation but at the expense of increasing the difficulties of analysis.

Another assumption generally made is, that the reaction constant is proportional to the amount of enzyme present, that is, $k /$ (enzyme quantity) remains constant. This seems to be at least approximately true in most instances. In table 2 , it is shown that for the hydrolysis of inulin by $A$. niger emulsin the quotient $\mathrm{k} / \mathrm{g}$ (where $g$ is grams of enzyme in $50 \mathrm{ml}$ of reaction mixture) exhibits an insignificant variation of about 10 percent when the enzyme quantity $(g)$ is varied twentyfold. A fiftyfold change in invertase concentration produces practically no change in the $\mathrm{k} / \mathrm{g}$ ratio for sucrose hydrolysis by $A$. niger emulsin No. 1, although an appreciable effect is observed for a hundredfold change of enzyme concentration.

TABLE 2.-Influence of enzyme concentration, enzyme stability, and effect of filtration of inulase and invertase of A. niger emulsin No. 1

\begin{tabular}{l|l|l|l|l|}
\hline Time & Hydrolysis $\left|k \times 10^{4}\right|$ & $g$ & $(k / g) \times 10^{4} \mid$ & Remarks \\
\hline
\end{tabular}

\section{INULASE}

$T=30.0^{\circ} \mathrm{C} ; \mathrm{pH}=4.0 ;$ inulin concentration $1.013 \mathrm{~g}$ in $50 \mathrm{ml}$ of reaction mixture

Influence of Enzyme Concentration

\begin{tabular}{l|r|r|r|r}
\hline $\min$ & Percent & & & \\
$80 \ldots$ & 41.1 & 28.7 & 0.542 & 58 \\
450 & 41.2 & 25.6 & .464 & 55 \\
$1,570 \ldots$ & 39.2 & 4.80 & .093 & 52 \\
\hline
\end{tabular}

Stability ${ }^{1}$ and Influence of Filtration ${ }^{2}$

\begin{tabular}{|c|c|c|c|c|c|}
\hline $\begin{array}{l}120 \\
120.3 \\
121.3 \\
121\end{array}$ & $\begin{array}{l}55.7 \\
54.0 \\
59.7 \\
57.7\end{array}$ & $\begin{array}{l}29.5 \\
28.0 \\
32.5 \\
30.9\end{array}$ & $\begin{array}{r}0.438 \\
.438 \\
.438 \\
.438\end{array}$ & $\begin{array}{l}67 \\
64 \\
74 \\
71\end{array}$ & $\begin{array}{l}\text { Filtered enzyme solution used. } \\
\text { Unfiltered enzyme solution used. } \\
\text { Filtered enzyme solution used after } 7 \text { days at } 30^{\circ} \mathrm{C} \text {. } \\
\text { Unfiltered enzyme solution used after } 7 \text { days at } \\
30^{\circ} \mathrm{C} \text {. } \\
\text { Acetate concentration in all the experiments was } \\
0.16 \mathrm{M} \text {. }\end{array}$ \\
\hline
\end{tabular}

INVERTASE

$T=30.0^{\circ} \mathrm{C} ; \mathrm{pH}=4.5$ (solution $0.16 \mathrm{M}$ in acetate ion)

Influence of Enzyme Concentration

$\left.\begin{array}{l|r|r|r|r}\hline 19 & 43.6 & 131 & 0.438 & 300 \\ 190 \ldots \ldots & 43.7 & 13.1 & .0438 & 300 \\ 965 \ldots \ldots & 44.6 & 2.66 & .00876 & 300 \\ 1,790 \ldots \ldots & 36.2 & 1.09 & .00438 & 250\end{array}\right\}$ Sucrose concentration was $2.375 \mathrm{~g}$ in $50 \mathrm{ml}$.

Stability ${ }^{1}$ and Influence of Filtration ${ }^{2}$

\begin{tabular}{|c|c|c|c|c|c|}
\hline $\begin{array}{l}15.0 \\
15.0 \\
15.0 \\
15.0\end{array}$ & $\begin{array}{l}43.4 \\
41.2 \\
45.5 \\
42.5\end{array}$ & $\begin{array}{l}165 \\
154 \\
176 \\
160\end{array}$ & $\begin{array}{r}0.438 \\
.438 \\
.438 \\
.438\end{array}$ & $\begin{array}{l}380 \\
350 \\
400 \\
370\end{array}$ & $\begin{array}{l}\text { Filtered enzyme solution used. } \\
\text { Unfiltered enzyme solution used. } \\
\text { Filtered enzyme kept at } 30^{\circ} \mathrm{C} \text { for } 7 \text { days. } \\
\text { Unfiltered enzyme kept at } 30^{\circ} \mathrm{C} \text { for } 7 \text { days. } \\
\text { Sucrose concentration in all the experiments was } \\
1.900 \mathrm{~g} \text { in } 50 \mathrm{ml} \text {. }\end{array}$ \\
\hline
\end{tabular}

1 The filtered and unfiltered solutions of footnote 2 were kept at $30^{\circ} \mathrm{C}$ for 7 days and then analyzed.

2 The enzyme preparation was made up to volume with water, and a portion was filtered before analysis. 
The results given in table 2 indicate that there is a slight increase (evaporation?) rather than a loss of activity as a result of keeping aqueous solutions of the $A$. niger emulsin for 7 days at $30^{\circ} \mathrm{C}$ when covered with a layer of toluene. It is possible that the buffered solutions (pH 4.0 to 4.5) used for the measurement of the effect of enzyme concentration may have produced some inactivation and that this may explain the decrease in the $k / g$ ratio observed for the longer time intervals in these experiments. It is also shown in the table that the insoluble material has no significant effect on the reaction.

In the present paper the measurement of the activity of the enzymes studied depends on the applicability of the first-order equation and on the constancy of the $\mathrm{k} / \mathrm{g}$ ratio. For the actual expression of activity, a quantity called the enzyme value $(E V)$ is used and is defined as $E V=k /(g \times \log 2)$, where $k$, the reaction constant under the Weidenhagen conditions of temperature and substrate concentration, is calculated by the first-order equation $k=(1 / t) \log (100 / 100-X), t$ is the time in minutes corresponding to $X$-percent hydrolysis, and $g$ is the weight of enzyme in $50 \mathrm{ml}$ of reaction mixture. The enzyme value is then the reciprocal of the time for 50-percent hydrolysis of the substrate for an emulsin concentration of 1 gram in $50 \mathrm{ml}$ of solution. For calculating $k$, Briggsian logarithms are used, but any base may be used for the enzyme value as long as $k$ and $\log 2$ are expressed similarly.

If the unit of enzyme quantity is taken as the amount of pure enzyme in $50 \mathrm{ml}$ of reaction mixture, which, under the standard conditions of Weidenhagen, produces a reaction constant, $k=\log 2$, then the enzyme value is equal to the number of enzyme units per gram of crude preparation. These arbitrary units are referred to hereafter as Weidenhagen units. Pringsheim and Ohlmeyer ${ }^{11}$, define the Pringsheim inulase unit as the amount of enzyme which produces 30-percent hydrolysis of $150 \mathrm{mg}$ of inulin in 1-percent solution in 3 bours at $37^{\circ} \mathrm{C}$. A comparison of this unit with the Weidenhagen unit, as previously defined, was made. The results in table 3 show that the enzyme preparation, which has an inulase value of 0.0174 (0.0174 units per gram), contains 35 Pringsheim units per gram. The Weidenhagen unit is then about 2,000 times larger than the Pringsheim unit. The table also shows that the inulin concentration used in the present investigation gives the same results, within the experimental error, as that used by Weidenhagen. However, in future work, it is intended to return to the Weidenhagen concentration.

TABLE 3.-Comparison of inulase units

[Enzyme concentration $=0.218 \mathrm{~g}$ of $A$. niger emulsin No. 1 in $50 \mathrm{ml}$ of reaction mixture]

\begin{tabular}{|c|c|c|c|c|c|c|c|}
\hline $\begin{array}{l}\text { Inulin } \\
\text { concen- } \\
\text { tration }\end{array}$ & $\begin{array}{l}\text { Temper- } \\
\text { ature }\end{array}$ & Time & Hydrolysis & $k \times 10^{4}$ & $E V$ & $\begin{array}{l}\text { Pringsheim } \\
\text { units } \\
\text { per gram }\end{array}$ & Remarks \\
\hline $\begin{array}{l}1.125 \\
1.013 \\
0.500\end{array}$ & $\begin{array}{l}{ }^{\circ} C \\
30.0 \\
30.0 \\
37.0\end{array}$ & $\begin{array}{r}\text { Min. } \\
248 \\
248 \\
162\end{array}$ & $\begin{array}{c}\text { Percent } \\
47.9 \\
49.2 \\
52.3\end{array}$ & $\begin{array}{l}11.4 \\
11.9 \\
19.8\end{array}$ & $\begin{array}{r}0.0174 \\
.0181 \\
-\end{array}$ & 35 & $\begin{array}{l}\text { Weidenhagen conditions. } \\
\text { Conditions in this paper. } \\
\text { Pringsheim conditions. }\end{array}$ \\
\hline
\end{tabular}

B One Pringsheim unit corresponds to $k=0.00086$. Since $0.150 \mathrm{~g}$ of inulin corresponds to $15 \mathrm{ml}$ of 1-percent solution, the enzyme unit is based on this volume and $g=0.218 \times 0.3$. The number of Pringsheim units is given by

$\frac{0.00198}{0.00086 \times 0.218 \times 0.3}=35.2$.

${ }^{11} \mathrm{H}$. Pringsheim and P. Ohlmeyer, Ber, deut. Chem. Ges, 65, 1242 (1932). 


\section{Journal of Research of the National Bureau of Standards}

Many different measures of enzyme activity have been employed for the carbohydrases. Although most methods depend on the constancy of the $k / g$ ratio, the experimental conditions of substrate concentration, temperature, etc., are so different that it is difficult to compare the reported activities. In an effort to clarify somewhat a very confusing situation, table 4 has been prepared to illustrate the differences between some of the more important methods.

TABLE 4.-Methods for the expression of glycosidase activity

\begin{tabular}{|c|c|c|c|c|c|}
\hline Name & $\begin{array}{c}\text { Formula for expressing } \\
\text { activity a }\end{array}$ & $\begin{array}{c}\text { Substrate } \\
\text { concentra- } \\
\text { tion }\end{array}$ & $\begin{array}{l}\text { Tempera- } \\
\text { ture of } \\
\text { measure- } \\
\text { ment }\end{array}$ & $\begin{array}{l}\text { Volume } \\
\text { used to } \\
\text { express } \\
\text { emulsin } \\
\text { concentra- } \\
\text { tion }\end{array}$ & References ${ }^{b}$ \\
\hline & & Moles/liter & ${ }^{\circ} \mathrm{C}$ & $m l$ & \\
\hline Enzymwert, or enzyme value. & $E V=\frac{k}{g \times \log 2}$ & 0.1388 & 30 & 50 & \\
\hline $\begin{array}{l}\text { Wertigkeit, or enzyme effi- } \\
\text { ciency. }\end{array}$ & $\begin{array}{l}W=E E=\frac{k}{g \times \log 2} \\
X f=\frac{k(S)}{g}\end{array}$ & .0520 & 30 & 50 & $\begin{array}{l}2 \\
3\end{array}$ \\
\hline Salicin spaltungsfähigkeit. & Sal. $f=\frac{k}{0}$ & $\begin{array}{l}.070 \\
.139\end{array}$ & $\begin{array}{l}30 \\
30\end{array}$ & $\begin{array}{l}50 \\
50\end{array}$ & $\begin{array}{l}4 \\
5\end{array}$ \\
\hline$k$ value & $k$ value $=\frac{100 k}{g_{1}}$ & & & 100 & 6 \\
\hline Time value (Zeitwert) & $t_{0}=\frac{0.6154 \times g_{2}}{k}$ & & 15.5 & 500 & 7,8 \\
\hline Saccharase-Wert. & $S W=\frac{1}{t_{0}}=\frac{k}{0.6154 \times g_{2}}$ & .467 & 15.5 & 500 & 8,7 \\
\hline
\end{tabular}

- Explanation of symbols:

$k=$ monomolecular reaction constant (Briggsian logarithms).

$g, g_{1}$, and $g_{2}=$ grams of emulsin in indicated volume.

$(S)=$ initial substrate concentration.

\section{b REFERENCES}

1. R. Weidenhagen, Z. Ver. deut. Zucker-Ind. 82992 (1932); see also footnote 7 of text.

2. B. Helferich, R. Gootz, and G. Sparmberg, Z physiol. Chem, 205201 (1932); B. Helferich and S. Winkler, 209, 269 (1932); W. W. Pigman, J. Research NBS 26, 197 (1941) RP1369. Previous to the article of Helferich and Winkler, a substrate concentration of 0.139 had been employed, but thereafter $0.052 \mathrm{M}$ solutions were used.

3. H. Von Euler and K. Josephson, Ber. deut. Chem. Ges. 56, 1749 (1923).

4. K. Josephson, Z. physiol. Chem. 147, 26, 31 (1925).

5. S. Veibel and $\mathbf{H}$. Lillelund, Kgl. Danske Videnskab. Selskab, Math. fys. Medd. 17 No. 6 (1940)

6. P. Gray and H. Rothchild, Ind. Eng. Chem. 13, 902 (1941).

7. See C. A. Browne and F. W. Zerban, Sugar Analysis, p. 437 (John Wiley \& Sons, Inc., New York, N. Y. 1941). This is a modification of the original directions of O'Sullivan and Tompson, J. Chem. Soc. 57, $834(1890)$.

8. R. Willstätter and R. Kuhn, Ber. deut. Chem. Ges. 56, 509 (1923).

\section{INVERTASE CONTENT OF ENZYME PREPARATIONS}

Table 5 summarizes the results obtained for the invertase activity of 14 enzyme preparations. The seven emulsins of fungal origin exhibit considerable ability to hydrolyze sucrose, but the most active of these has only about 1 percent of the activity of a commercial yeast invertase (yeast emulsin No. 1). It is interesting to note that the total variation in invertase activity of the fungal preparations is only some sevenfold, and since the least active of these contained a diluent, the variation is still less.

The one bacterial emulsin investigated showed a negligible invertase content, and the pancreatic extracts are similar in this respect. The wheat, malt, and almond emulsins exhibited a very slight invertase activity. 
TABLE 5.-Invertase content $(E V)$ of enzyme preparations

[Sucrose concentration $=2.375 \mathrm{~g}$ in $50 \mathrm{ml}$ of reaction mixture; $T=30^{\circ} \mathrm{C}$.]

\begin{tabular}{|c|c|c|c|c|c|c|c|c|}
\hline \multirow{2}{*}{ Enzyme preparation } & \multicolumn{4}{|c|}{$\begin{array}{l}\mathrm{pH}=4.5 \text { (approx); acetate-ion } \\
\text { concentration }=0.2 \mathrm{M}\end{array}$} & \multicolumn{4}{|c|}{$\begin{array}{c}\mathrm{pH}=6.7 \text { (approx); phosphate } \\
\text { concentration }=0.05 \mathrm{M}\end{array}$} \\
\hline & Time & $\begin{array}{c}\text { Hydrol- } \\
\text { ysis }\end{array}$ & $g$ & $\underset{10^{4}}{E V \times}$ & Time & $\begin{array}{l}\text { Hydrol- } \\
\text { ysis }\end{array}$ & $g$ & $\underset{10^{4}}{E V X}$ \\
\hline & $\min$ & Percent & & & $\min$ & Percent & & \\
\hline A. oryzae emulsin No. 1 . & 110 & 55.0 & a 0.251 & 420 & 224 & 49.4 & a 0.501 & 88 \\
\hline $\begin{array}{l}\text { A. oryzae emulsin No. } \\
\text { A. oryzae emulsin No. } 2 \text { (purified) }\end{array}$ & $\begin{array}{l}73 \\
50\end{array}$ & $\begin{array}{l}29.6 \\
32.6\end{array}$ & $\begin{array}{l}.563 \\
.563\end{array}$ & $\begin{array}{l}120 \\
200\end{array}$ & $\begin{array}{l}97 \\
80\end{array}$ & $\begin{array}{l}35.8 \\
36.8\end{array}$ & $\begin{array}{l}.563 \\
.563\end{array}$ & $\begin{array}{l}120 \\
150\end{array}$ \\
\hline A. oryzae emulsin No. & 45.6 & 43.7 & .563 & 320 & 79 & 42.5 & .563 & 180 \\
\hline A. niger emulsin No. 1 . & 46 & 48.4 & a. 218 & 950 & 268 & 37.4 & a. 218 & 120 \\
\hline A. niger emulsin No. 2 & 121 & 41. 2 & a. 256 & 250 & 231 & 41.1 & a. 511 & 65 \\
\hline B. mesentericus emulsin No. 1 . & 1,500 & $(.3)$ & .563 & $(.05)$ & 1,440 & $(.3)$ & .563 & $(.05)$ \\
\hline Wheat emulsin No. 1 & 1,380 & .6 & .563 & .11 & 1,440 & $(.3)$ & .563 & $(.05)$ \\
\hline Malt emulsin No. 1 ...... & 1,440 & 9.1 & .563 & 1.7 & 1,440 & 1.7 & .563 & .3 \\
\hline Almond emulsin No. $1 \ldots$ & $\overrightarrow{1}, 440$ & 7.5 & a. 400 & 2.0 & 1,440 & 6.4 & a. 400 & 1.7 \\
\hline Pancreatic emulsin No. 1 & 1,440 & $(.3)$ & .563 & $(.05)$ & 1,440 & (.3) & .563 & $(.05)$ \\
\hline Pancreatic emulsin No. $2 \ldots$ & 1,440 & $(.3)$ & .563 & $(.05)$ & 1,485 & 4. 0 & .563 & 0.7 \\
\hline Yeast emulsin No. $1 \ldots$ & 30 & 36.8 & .00257 & 86,000 & 70 & 47. 7 & .00257 & 52,000 \\
\hline Aspergillus emulsin No. $1 \ldots$ & 30 & 37.1 & .563 & 400 & 62 & 45.5 & .563 & 250 \\
\hline Yeast emulsin (Weidenhagen) & 8 & 30.1 & .020 & 32,000 & & & & \\
\hline
\end{tabular}

aBased on soluble material of emulsin.

With one exception (No. 1), the Aspergillus oryzae emulsins exhibit less variation in activity between the two hydrogen-ion concentrations at which the measurements were carried out than do the Apergillus niger emulsins. As demonstrated in table 6, this is to be ascribed to the difference in the optimal $\mathrm{pH}$ for the two classes of fungi. The $\mathrm{pH}$ optimum for the $A$. niger invertase seems to lie in the $\mathrm{pH}$ interval 3 to 4 , and that for the $A$. oryzae invertase near $\mathrm{pH} 5.0$. This property of the A. niger invertase may be of particular importance when it is desired to carry out the inversion of sucrose at acidities greater than that optimal for yeast invertase. The $A$. oryzae emulsin No. 1 behaves more like the $A$. niger emulsins, but whether this may be due to an incorrect classification cannot be stated at present. The Aspergillus emulsin No. 1 seems to be similar in properties to the A. oryzae emulsins.

TABLE 6.-Effect of $\mathrm{pH}$ on activity of invertases

[Sucrose concentration $=2.376 \mathrm{~g}$ in $50 \mathrm{ml}$ of reaction mixture; acetate-ion concentration $=0.16 \mathrm{M} ; 7=30.0^{\circ} \mathrm{C}$.]

\begin{tabular}{|c|c|c|c|c|c|c|c|}
\hline \multicolumn{4}{|c|}{$\begin{array}{l}\text { A. niger emulsin No. } 1 \\
g=0.0438 \mathrm{~g} \text { in } 50 \mathrm{ml}\end{array}$} & \multicolumn{4}{|c|}{$\begin{array}{l}\text { A. oryzae No. } 2 \text { (purified) } \\
g=0.282 \mathrm{~g} \text { in } 50 \mathrm{ml}\end{array}$} \\
\hline $\mathrm{pH}$ & Time & Hydrolysis & $(k / g) \times 10^{4}$ & $\mathrm{pH}$ & Time & Hydrolysis & $(k / g) \times 10^{4}$ \\
\hline $\begin{array}{l}3.0 \\
4.0 \\
4.45 \\
5.0\end{array}$ & $\begin{array}{l}\min \\
157.5 \\
170 \\
195 \\
180.5\end{array}$ & $\begin{array}{c}\text { Percent } \\
47.4 \\
48.6 \\
50.1 \\
38.5\end{array}$ & $\begin{array}{l}400 \\
390 \\
350 \\
270\end{array}$ & $\begin{array}{l}4.0 \\
4.5 \\
5.0 \\
5.5\end{array}$ & $\begin{array}{l}\min \\
80 \\
80 \\
80 \\
80\end{array}$ & $\begin{array}{c}\text { Percent } \\
26.3 \\
28.6 \\
30.0 \\
29.8\end{array}$ & $\begin{array}{l}59 \\
65 \\
69 \\
68\end{array}$ \\
\hline
\end{tabular}

The hydrolysis of sucrose by $A$. oryzae emulsin (Takadiastase) was studied by Weidenhagen, ${ }^{12}$ and the results are in agreement with those of the present investigation in indicating that the optimal $\mathrm{pH}$ is around 5.0 .

${ }^{12}$ R. Weidenhagen, Z. Ver, deut. Zucker-Ind. 78, 125 (1928). 
The kinetics of the hydrolysis of sucrose by the invertase in commercial Takadiastase have been investigated..$^{13}$ It was claimed that the reaction proceeds more slowly than demanded by the first-order equation (decreasing reaction constants), and that the hydrolysis of sucrose by yeast invertase proceeds more rapidly than required by the first-order equation (increasing reaction constants). It is shown in table 1 that the hydrolysis by the $A$. niger emulsin follows the first-order equation fairly closely. As previously mentioned, however, the writer believes that this problem requires additional investigation before the kinetics can be known with certainty.

\section{INULASE CONTENT OF ENZYME PREPARATIONS}

It has been known from earlier work that emulsins from $A$. niger have considerable ability to hydrolyze inulin to levulose. ${ }^{14}$ Commercial yeast emulsin (invertase) also is known to catalyze the hydrolysis of inulin, ${ }^{15}$ and numerous references of a qualitative nature are to be found on the occurrence of inulases in various fungi. ${ }^{16}$

The results of the present investigation are in agreement with this previous work, as table 7 demonstrates. The $A$. niger emulsins and the $A$. oryzae emulsin No. 1 have considerable inulase activity, and the other Aspergillus emulsins have a slight but definite activity. As was pointed out for the invertase activity, the $A$. oryzae emulsin No. 1 resembles those for the $A$. niger preparations rather than the other $A$. oryzae preparations. The plant, bacterial, and pancreatic emulsins exhibit no appreciable inulase activity.

TABLE 7.-Inulase content of enzyme preparations

[Inulin concentration $=1.013 \mathrm{~g}$, of anhydrous inulin in $50 \mathrm{ml}$ of reaction mixture; $T=30.0^{\circ} \mathrm{C}$.]

\begin{tabular}{|c|c|c|c|c|c|c|c|c|c|}
\hline \multirow{2}{*}{ Enzyme preparation } & \multicolumn{4}{|c|}{$\mathrm{pH}=4.5$ (approx) (acetate buffer) } & \multicolumn{4}{|c|}{$\begin{array}{l}\mathrm{pH}=6.5 \text { (approx) } \\
\text { (phosphate buffer) }\end{array}$} & \multirow{2}{*}{$\begin{array}{c}\text { Ratio o: } \\
\text { Invert- } \\
\text { ase } \\
\text { value } \\
\begin{array}{c}\text { Inulase } \\
\text { value }\end{array}\end{array}$} \\
\hline & Time & $\begin{array}{c}\text { Hydrol- } \\
\text { ysis }\end{array}$ & $g$ & $\begin{array}{l}\text { d } E V \\
\times 10^{6}\end{array}$ & Time & $\begin{array}{c}\text { Hydrol- } \\
\text { ysis }\end{array}$ & $g$ & $\begin{array}{l}\text { d } E V \\
\times 10^{\circ}\end{array}$ & \\
\hline $\begin{array}{l}\text { A. oryzae emulsin No. } 1 \\
\text { A. oryzae emulsin No. } 2 \\
\text { A. oryzae emulsin No. } \\
\text { (purified) } \\
\text { A. oryzae emulin No. } 3 \\
\text { A. niger emulsin No. } 1 \\
\text { A. niger emulsin No. } 2 \\
\text { Aspergillus emulsin No. } 1 \\
\text { Yeast emulsin No. } 1 \\
B \text {. mesentericus emulsin } \\
\text { No. } 1 . \\
\text { Wheat emulsin No. } 1 \\
\text { Malt emulsin No. } 1 \\
\text { Almond emulsin No. } 1 \\
\text { Pancreatic emulsin No. } 1 \\
\text { Pancreatic emulsin No. } 2\end{array}$ & $\begin{array}{l}\text { Min } \\
1,440 \\
1,440 \\
1,440 \\
1,440 \\
600 \\
1,440 \\
1,500 \\
1,465 \\
1,440 \\
1,440 \\
1,440 \\
1,440 \\
1,440 \\
1,440\end{array}$ & \begin{tabular}{r|} 
Percent \\
a 78.9 \\
2.7 \\
2.7 \\
15.1 \\
$\mathrm{8} 84.9$ \\
$\mathrm{a} 64.4$ \\
3.5 \\
40.8 \\
$(0.7)$ \\
$(.7)$ \\
1.6 \\
$(.7)$ \\
$(.7)$ \\
$(.3)$
\end{tabular} & $\begin{array}{l}\text { b } 0.251 \\
1.13 \\
1.13 \\
1.13 \\
\text { b } 0.218 \\
\text { b. } 256 \\
.563 \\
.257 \\
1.13 \\
1.13 \\
1.13 \\
0.803 \\
.564 \\
.563\end{array}$ & $\begin{array}{r}\text { \& } 5800 \\
24 \\
24 \\
150 \\
\text { a } 19,700 \\
\text { a } 3,900 \\
61 \\
2,000 \\
(6) \\
(6) \\
14 \\
(9) \\
(13) \\
(5)\end{array}$ & $\begin{array}{l}\text { Min } \\
1,440 \\
1,440 \\
1,440 \\
1,440 \\
1,440 \\
1,440 \\
1,440 \\
1,440 \\
1,440 \\
1,440 \\
1,440 \\
1,440 \\
1,440 \\
1,440\end{array}$ & $\begin{array}{r}\text { Percent } \\
30.7 \\
1.5 \\
(0.7) \\
8.6 \\
67.6 \\
27.2 \\
5.8 \\
12.9 \\
(0.7) \\
(.7) \\
(.7) \\
(.7) \\
(.7) \\
(.3)\end{array}$ & $\begin{array}{c}\text { b } 0.501 \\
1.13 \\
\\
1.13 \\
1.13 \\
\text { b } 0.437 \\
\text { b. } 511 \\
.563 \\
.257 \\
1.13 \\
1.13 \\
1.13 \\
0.803 \\
1.13 \\
0.563\end{array}$ & $\begin{array}{r}740 \\
13 \\
\\
(6) \\
80 \\
2,600 \\
620 \\
110 \\
540 \\
\\
(6) \\
(6) \\
(6) \\
(9) \\
(6) \\
(5)\end{array}$ & $\begin{array}{c}7.2 \\
500 \\
\\
830 \\
210 \\
4.8 \\
6.4 \\
660 \\
4,300\end{array}$ \\
\hline
\end{tabular}

a These values are from data in table 1 and are for $\mathrm{pH}=4.0$. The enzyme value is the average value. b Based on soluble material.

c Calculated from values in this table and table 5 for $\mathrm{pH}=4.5$ or 4.0 .

d Parenthesis indicate maximum values calculated on the basis of a maximum iodine consumption of $0.3 \mathrm{ml}$.

13 R. Weidenhagen and B. Dey, Z. Ver. deut. Zucker-Ind. 78, 242 (1928).

14 H. Pringsheim, and W. G. Hensel, Ber. deut. Chem. Ges. 64, 1431 (1931); H. Pringsheim and P. Ohl. meyer, Ber. deut. Chem. Ges. 65, $1242(1932)$.

15 R. Weidenhagen, Z. Ver. deut. Zucker-Ind. 82, 316, 912 (1932).

16 A. C. Thaysen and L. D. Galloway, Microbiology of Starch and Sugars, p. 36 (Oxford University Press, London, 1930). 
In agreement with Weidenhagen's earlier results, a commercial yeast emulsin (yeast invertase preparation), has a considerable inulase content, which seems to be about one-seventh of that in the most active $A$. niger material. The enzyme value of the yeast emulsin used by Weidenhagen may be calculated from his data, since very similar conditions were used. Using an average " $k$ " as 0.0019 (see p. 914 of reference in footnote 15), the inulase value is calculated as $63,000 \times$ $10^{-6}$ for a yeast emulsin which had received considerable purification (invertase value $=\beta$-h-Fructosidase-Wert $=333$, as compared to values of 3 to 9 for commercial yeast invertases).

The optimal $\mathrm{pH}$ for the inulase action of the $A$. niger emulsins and the $A$. oryzae emulsin No. 1 is less than $\mathrm{pH} 4$ and probably is around $\mathrm{pH} 3$ (see table 8). The lowest $\mathrm{pH}$ values are for the enzymer in $0.2 \mathrm{M}$ acetic acid solution. The measurements could not be carried into the more acid region without changing the nature of the buffer. It is of interest that the optimal $\mathrm{pH}$ is near the region of maximal stability of levulose, $\mathrm{pH} 3.3 .{ }^{17}$

TABLE 8.-Effect of $\mathrm{pH}$ on activity of inulases

$\left[T=30.0^{\circ} \mathrm{C}\right]$

\begin{tabular}{|c|c|c|c|c|c|c|c|c|}
\hline \multicolumn{3}{|c|}{$\begin{array}{l}\text { A. oryzae emulsin No. } 1 . \\
\text { Inulin concentration }=1.013 \mathrm{~g} \\
\text { in } 50 \mathrm{ml} \text { of reaction mixture. } \\
\text { Acetate-ion concentra- } \\
\text { tion }=0.20 \mathrm{M} \text {. } \\
g=0.250 \mathrm{~g} \text { of enzyme in } 50 \mathrm{ml} \\
\text { of reaction mixture. }\end{array}$} & \multicolumn{3}{|c|}{$\begin{array}{c}\text { A. niger emulsin No. } 1 . \\
\text { Inulin concentration }=0.810 \mathrm{~g} \\
\text { in } 50 \mathrm{ml} \text { of reaction mixture. } \\
\text { Acetate-ion concentra- } \\
\text { tion }=0.16 \mathrm{M} \text {. } \\
g=0.0871 \mathrm{~g} \text { in } 50 \mathrm{ml} \text { of reaction } \\
\text { mixture. }\end{array}$} & \multicolumn{3}{|c|}{$\begin{array}{l}\text { A. niger emulsin No. } 2 . \\
\text { Inulin concentration }=0.810 \mathrm{~g} \\
\text { in } 50 \mathrm{ml} \text { of reaction mixture. } \\
\text { Acetate-ion concentra- } \\
\text { tion }=0.16 M \text {. } \\
g=0.204 \mathrm{~g} \text { in } 50 \mathrm{ml} \text { of reaction } \\
\text { mixture. }\end{array}$} \\
\hline $\mathrm{pH}$ & $\begin{array}{l}\text { Hydrolysis } \\
\text { after } 24 \mathrm{hr}\end{array}$ & $k / g \times 10^{4}$ & $\mathrm{pH}$ & \begin{tabular}{|c|} 
Hydrolysis \\
after $24 \mathrm{hr}$
\end{tabular} & $k / g \times 10^{4}$ & $\mathrm{pH}$ & $\begin{array}{l}\text { Hydrolysis } \\
\text { after } 24 \mathrm{hr}\end{array}$ & $k / g \times 10^{4}$ \\
\hline $\begin{array}{r}-3.7 \\
4.1 \\
4.6 \\
5.1\end{array}$ & $\begin{array}{c}\text { Percent } \\
82.8 \\
82.2 \\
79.6 \\
74.0\end{array}$ & $\begin{array}{l}21 \\
21 \\
19 \\
16\end{array}$ & $\begin{aligned} \text { 8 } 3.3 \\
4.1 \\
4.5 \\
5.0\end{aligned}$ & $\begin{array}{c}\text { Percent } \\
90.7 \\
87.1 \\
86.2 \\
80.2\end{array}$ & $\begin{array}{l}82 \\
71 \\
69 \\
56\end{array}$ & $\begin{array}{r}\text { × } 3.3 \\
4.1 \\
4.5 \\
5.0\end{array}$ & $\begin{array}{c}\text { Percent } \\
64.0 \\
61.7 \\
60.6 \\
52.2\end{array}$ & $\begin{array}{l}15 \\
14 \\
14 \\
11\end{array}$ \\
\hline
\end{tabular}

- The reaction mixture, made up, using $0.2 \mathrm{M}$ acetic acid, had the indicated $\mathrm{pH}$ in the presence of the enzyme.

The rate of hydrolysis of inulin by three Aspergillus emulsins was studied, and the results are recorded in table 1. Within a deviation of less than 10 percent, the reaction appears to follow the first-order equation, particularly when degrees of hydrolysis less than 20 and more than 80 percent are eliminated.

A comparison of the inulase activity at $30.0^{\circ}$ and $50.0^{\circ} \mathrm{C}$, of the $A$. oryzae preparation (see table 1 ) shows that the reaction rate is accelerated about 2.5 times when the temperature is changed from $30.0^{\circ}$ to $50.0^{\circ} \mathrm{C}$. This corresponds to an activation energy of $8,900 \mathrm{cal}$.

\section{ACTION OF INULASE ON EXTRACTS FROM JERUSALEM ARTICHOKES}

Inulin and similar polysaccharides occurring in the tuber of the jerusalem artichoke (Helianthus tuberosus) and in the dahlia, chicory, burdock, goldenrod, and dandelion plants have shown considerable promise for the production of crystalline levulose ${ }^{18}$ and for the produc-

17 J. A. Mathews and R. F. Jackson, BS J. Research 11. 619 (1933) RP611.

18 R. F. Jackson, C. G. Silsbee, and M. J. Proffitt, BS Sci. Pap. 20, 587 (1926) S519; F. J. Bates, Sugar 28, 167 (1926); NBS Letter Circular LC500 (1937). 
tion of fermentable and/or edible levulose sirups. ${ }^{19}$ Most of the methods used depend on acid hydrolysis, although, as shown by the investigations of Jackson, McDonald, and Goergen, ${ }^{20}$ purified inulin gives a mixture of sugars consisting of about 92 percent of fructose, 5 percent of nonreducing difructose anhydrides, and 3 percent of $D$-glucose. This loss of levulose, due to the formation of the difructose anhydrides and possibly of glucose, is disadvantageous not only in the direct loss sustained but also in lowering the purity. ${ }^{21}$ Weidenhagen has reported that inulin is quantitatively hydrolyzed by yeast emulsin (yeast invertase preparations) to reducing sugars. ${ }^{22}$ In the present investigation, hydrolyses of from 98.8 to 100.0 percent were observed. Within the experimental error, the hydrolysis seems to be complete. ${ }^{23}$

The results outlined for the pure inulin made it desirable to carry out the same experiments with juices from the jerusalem artichoke. These were prepared by pressing the artichokes in a hydraulic press, soaking the residue in hot water, and repressing. The juice, which contained 10.8 percent of dry substance (by refractometer), had a $\mathrm{pH}$ of 6.2 and a density of 1.039 at $20^{\circ} \mathrm{C}$. After hydrolysis with 0.33 $M$ hydrochloric acid for 60 minutes at $80^{\circ} \mathrm{C}$, the juice contained $0.0944 \mathrm{~g}$ of reducing sugar per milliliter (calculated as levulose in undiluted, hydrolyzed juice). For the enzyme hydrolysis, $20 \mathrm{ml}$ of juice was acidified to $\mathrm{pH} 4.2$ with hydrochloric acid, $0.400 \mathrm{~g}$ of $A$. oryzae emulsin No. 1 added, and the solution diluted to $25 \mathrm{ml}$. After 72.5 hours at $30^{\circ} \mathrm{C}$, the solution had $0.0983 \mathrm{~g}$ per milliliter of reducing sugar, and after 91 hours, $0.0975 \mathrm{~g}$ (calculated as levulose per milliliter of undiluted juice). These results indicate that the hydrolysis is practically quantitative, since for inulin itself, the enzymic hyrdolysis gives about 5 percent more reducing sugar than the acid hydrolysis. Although only of a preliminary nature, these experiments would seem promising for application to the large-scale hydrolysis of juices containing levulose polysaccharides. The commercial utilization would, however, depend on the cost of the enzyme preparation, although some allowance would have to be made for the higher yields of reducing sugar, the savings due to the smaller amounts of acids, lime, and heat required, and to the probable increase in ease of crystallization due to the milder conditions employed.

\section{COMPARISON OF INULASE AND INVERTASE ACTIVITY}

Weidenhagen has presented a scheme for the classification of hydrolytic carbohydrases, which is of considerable value and has stimulated considerable research. ${ }^{24}$ As originally stated, the system demanded that there be only one enzyme for each $\alpha$ - and one for each $\beta$-glycosidic type. One enzyme should hydrolyze all $\beta$ - $D$-glucosides ( $\beta$-glucosidase), one all $\alpha$ - $D$-glucosides ( $\alpha$-glucosidase), one all $\alpha$ - $D$-galactosides ( $\alpha$-galactosidase), etc. He considered the disaccharides as glycosides and that the same enzyme should hydrolyze related polysaccharides, disaccharides, and glycosides. The system required that $\beta$-glucosi-

\footnotetext{
${ }_{10}$ R. T. Wendland, E. Fulmer, and L. Underkofler, Ind. Eng. Chem. 33, 1078 (1941); DT. Englis and H. A. Fiess, 34, 864 (1942).

20 E. J. McDonald and R. F. Jackson, J. Research NBS 24, 181 (1940) RP1277.

21 R. F. Jackson and J. A. Mathews, J. Research NBS 15, 341 (1935) RP832.

22 R. W eidenhagen, Z. Ver. deut. Zucker-Ind. 82, 316 , 512 (1932).

${ }_{23}$ This agrees with the results found by M. Adams, N. K. Richtmyer, and C. S. Hudson, who have very kindly informed the writer of the unpublished results of their study of the action of purified yeast invertase on inulin.

${ }_{24}$ R. Weidenhagen, Ergebn. Enzymforsch. 1, 168 (1932).
} 
dase hydrolyze alkyl and aryl $\beta$ - $D$-glucosides, cellobiose, and gentiobiose. Similarly, $\alpha$-glucosidase should catalyze the hydrolysis of alkyl and aryl $\alpha-D$-glucosides as well as maltose, and invertase ( $\beta$-fructofuranosidase) should hydrolyze both sucrose and inulin.

In previous papers, evidence was given that the $\beta$-glucosidase and the $\beta$-galactosidase of almond emulsin probably hydrolyze the corresponding glycosides and disaccharides, ${ }^{25}$ and the results obtained for the present series of preparations furnish additional information of interest in this connection.

A comparison of the invertase and inulase activities of the same enzyme preparations is made in the last column of table 7. In considering the comparison, it should be remembered that the conditions used for making the activity determinations are extremely arbitrary, and that for other conditions, the ratios are different. If the same part of the enzyme molecule is responsible for both the hydrolysis of inulin and sucrose, and if, as originally stated by Weidenhagen, there is only a single invertase, then the ratio of the invertase to inulase activity should be independent of the source of the material. The ratios in table 7 , however, vary from about 5 for $A$. niger emulsins to more than 4,000 for yeast emulsin, and the other Aspergillus preparations fall between these extremes. According to unpublished work of M. Adams, N. K. Richtmyer, and C. S. Hudson, who have generously allowed their results to be quoted, highly purified baker's yeast invertase (enzyme value about 1,000 ) exhibits a ratio for these activities of 2,800 and a highly purified brewer's yeast preparation 28,300 . The variation is then from about 5 to 28,000 . These results agree with those previously obtained by other workers, ${ }^{26}$ who have found that enzymes from different sources but hydrolyzing the same type of linkage have different specificities.

This evidence would seem to be ample proof that the unmodified Weidenhagen theory is untenable. The ascribing of these differences by Weidenhagen and Renner to variations in the "Träger" is not valid, as carbohydrates apparently do not dissociate ${ }^{27}$ to yield coenzymes and carriers ("Träger"). Since the entire molecule must be termed the enzyme, appreciable changes in a part would produce a new molecule and, therefore, a new enzyme.

\section{EXPERIMENTAL PROCEDURE}

\section{ENZYME PREPARATIONS (EMULSINS)}

Some of the emulsins studied in this investigation are principally commercial preparations developed specifically for enzymes not investigated in the present work, and others are purely experimental. Most of the information given was provided by the manufacturers, who also, in all instances, classified the microorganisms. Since the preparations are usually standardized for some particular enzyme activity other than that studied, it is quite probable that considerable variation may be expected for the emulsin prepared at different times. For all emulsins except those of pancreatic origin, the weights

\footnotetext{
${ }^{25}$ B. Helferich and W. W. Pigman, Ber. deut. chem. Ges. 72, 212 (1939); W. W. Pigman, J. Research NBS 27, 1 (1941) RP1398.

${ }_{26}$ H. Pringsheim, H. Borchardt, and F. Loew, Z. physiol. Chem. 202, 23 (1931); B. Helferich and F. Vorsatz, Z. physiol. Chem. 237, 254 (1935); K. Myrbäch and S. Myrbäch, Svensk Kem. Tid. 48, 64 (1936); R. Weidenhagen and A. Renner, Z. Ver. deut. Zucker-Ind. 86, 22 (1936).

${ }_{27}$ B. Helferich, R. Hiltmann, and W. Pigman, Z. physiol. Chem. 259, 150 (1939).
} 
(grams) in $50 \mathrm{ml}$ of solution represent the soluble material of the preparation. For those containing appreciable quantities of insoluble material (A. oryzae No. 1, A. niger Nos. 1 and 2, almond emulsin No. 1), the soluble material was determined by filtering the aqueous enzyme solution and evaporating it to constant weight in a vacuum desiccator over calcium chloride. Except for emulsins which had been diluted with sugars, the reducing sugar equivalent (as glucose) varied from about $7 \mathrm{mg} / \mathrm{g}$ of emulsin to $70 \mathrm{mg} / \mathrm{g}$. As a rule, the plant emulsins seem to have a higher reducing power than those from microorganisms or pancreases. In purchasing emulsins, it may be desirable to specify the diluent desired.

\section{(a) EMULSINS FROM PLANT EXTRACTS}

These are extracts of seeds, in some instances after a pretreatment, from which the enzymes have been precipitated. The malt emulsin is probably similar to the well-known commercial "Malt extract", for which the preparation is given in the U. S. Dispensatory. ${ }^{28}$

A review of the enzymes of barley has been made by Glick. ${ }^{29}$

Malt Emulsin No. 1.-(Malt diastase preparation, by courtesy of the Wallerstein Laboratories.) "The product was prepared from malt by extraction and salt precipitation. It was standardized to a Lintner value of 1,000 , using sodium sulfate as a diluent. Contains a mixture of alpha and beta amylase and in addition small amounts of proteolytic enzymes." The material dissolves in water with only a slight residue.

Wheat Emulsin No. 1.-(Beta-Amylase, furnished by courtesy of the Wallerstein Laboratories.) "This is a preparation which was made from wheat by extraction and salt precipitation. It is substantially but not entirely free from alpha amylase. Lintner value 1,000, standardized to uniform Lintner strength, using sodium sulfate as diluent." A considerable quantity of insoluble material is present in the solid emulsin.

Almond Emulsin No. 1.- (Furnished by courtesy of B. F. Helferich, of the University of Leipzig.) This is the "Rohferment" of Helferich, ${ }^{30}$ which is prepared from sweet almond kernels by zinc sulfate treatment and tannin precipitation. The composition of this material has been studied in recent years by Helferich and associates. ${ }^{31}$ The solid emulsin contains about 71 percent of soluble material.

\section{(b) EMULSINS FROM ANIMAL ORGANS}

The present study includes only pancreatic preparations. These are probably similar in composition to the well-known "Pancreatin", for which the preparation is given in the U. S. Dispensatory. ${ }^{32}$

Pancreatic Emulsin No. 1.- (Degomma 160 A, furnished by the courtesy of the Röhm \& Haas Co.) The manufacturer states: "Degomma $160 \mathrm{~A}$ is prepared from swine pancreas extract by selective precipitation. The Degomma $160 \mathrm{~A}$ has high amylase activity. It dissolves practically completely in water."

Pancreatic Emulsin No. 2.-(Pancreas Substance, obtained from Armour \& Co.) The manufacturer states: "The material is manufactured from hog pancreas activated by the use of enterokinase from the hog duodenum. It is vacuum dried, defatted, and ground to a fine powder. The whole pancreatic gland is included in the product." A considerable quantity of undissolved material remains when the substance is shaken with water.

\section{(c) EMULSINS FROM MICROORGANISMS}

The general procedures followed in the preparation of enzyme mixtures from microorganisms are well known, but the details are

28 22d ed., p. 459 (J. B. Lippincott Co., Philadelphia, Pa. (1937)).
29 D. Glick, Wallerstein Lab. Comm. 4, No. 11, 20 (1941).

${ }_{30}$ B. Helferich and S. Winkler, R. Gootz, O.Peters, and E. Günther, Z. physiol. Chem. 208, 91 (1932).

31 B. Helferich, Ergebn. Enzymforsch. $\boldsymbol{y}, 83$ (1938).

${ }_{32} 22$ d ed., p. 808, J. B. Lippincott Co., Philadelphia, Pa. (1937). 
usually trade secrets. The processes involved have been reviewed, ${ }^{33}$ and the following may be considered a typical procedure.

Wheat bran to which nutrient substances have been added is sterilized by steam, and the moist material is placed in trays to a depth of about 1 inch. After inoculation with spores, the material is allowed to stand while the fungus grows. The temperature is controlled by passing air between the trays. When the optimal development has been attained, the mass is extracted with water and an extract containing 10 to 20 percent of solids if obtained. The enzymes and contaminating material are precipitated by the addition of alcohol or other material and dried in air.

For bacterial emulsins, the process is similar except that aerated solutions are frequently used and the enzymes are excreted directly into the nutrient medium, which, after separation of the bacteria, is treated similarly to the fungal extract to obtain the dry emulsin.

Aspergillus oryzae Emulsin No. 1.-(Maltase No. 16, furnished by courtesy of the Röhm \& Haas Co.) This is a preparation developed for its $\alpha$-glucosidase (maltase) activity and contains active amylases. It is produced from an active strain of $A$. oryzae and contains 89 percent of water-soluble material.

Aspergillus oryzae Emulsin No. 2.- (Fungal enzyme furnished by courtesy of the Wallerstein Laboratories.) "This is a highly active enzyme prepared from Aspergillus oryzae by extraction, purification, and salt precipitation. It has been standardized, using sodium sulfate as a diluent, to a Lintner value of 1,000 and ordinarily contains lactose as a carrier. It contains besides an amyolytic enzyme, considerable amounts of proteolytic enzymes, cytases, phosphatases, and maltase." The material is practically completely soluble in water.

Aspergillus oryzae Emulsin No. 2, purified.-(Mylase P for Thiamin determination, furnished by courtesy of the Wallerstein Laboratories.) "This represents a specially fractionated mixture from the same source as the above, and has been found to be rich in phosphatase, cytases, and hemicellulases, and contains some maltase." Since it is not known that this material represents solely the effects of purification of Emulsin No. 2, differences between the two emulsins cannot be considered as significant in this respect. The material is completely soluble in water.

Aspergillus oryzae Emulsin No. 3.-(Takadiastase purchased fiom the Takamine Laboratories.) This is crude undiluted takadiastase ( 970 percent) which, according to the literature, is prepared from A. oryzae. (I. Effront, Chem. et Ind. 43,

3 (1904); J. Takamine, Ind. Eng. Chem. 6, 824 (1914). The Takadiastase has been extensively studied by many workers. ${ }^{34}$ The material dissolves with only a slight residue.

Aspergillus niger Emulsin No. 1.-(Cellulase No. 55, furnished by courtesy of the Röhm \& Haas Co.) This preparation was developed for its cellulose hydrolyzing ability. The material contains 77 percent of water-soluble substance.

Aspergillus niger Emulsin No. 2.-(Enzyme $100 \mathrm{D}$ purchased from the Röhm $\&$ Haas Co.) This is a commercial preparation from A. niger. Polygalacturonic acid is converted to galacturonic acid in high yield by the preparation. ${ }^{35}$ Diatomaceous earth has been used as a diluent. The material contains 91 percent of water-soluble substance.

Aspergillus Emulsin No. 1.-(Polidase No. 566, furnished by courtesy of the Schwarz Laboratories.) The manufacturer reports the following enzymes to be present in considerable amounts: proteases, $\alpha$-amylase, $\beta$-amylase, maltase, acid phosphatase, $\beta$-glucosidase, catalase, and nucleases. $\beta$-Galactosidase(lactase), invertase, and lipase are reported in fair quantities; inulase, in small quantities; and urease, peroxidase, and carboxylase are absent. The emulsin dissolves in water to give a clear solution.

Bacillus mesentericus Emulsin No. 1.-(Special Rapidase, furnished by courtesy of the Wallerstein Laboratories.) "This represents an experimental preparation

${ }^{33}$ I. Effront, Chem. et Ind. 43, 3 (1940); J. Takamine, Ind. Eng. Chem. 6, 824 (1914); L. Wallerstein, Wallerstein Lab. Comm. No. 7, p. 5 (December (1939).

34 R. Weidenhagen, Z. Ver. deut. Zucker-Ind. 78, 125, 243 (1928); K. Aizawa, Enzymologia 6, 321 (1939); T. Harada, Ind. Eng. Chem. 23, 1424 (1931), and many others.

${ }_{35}$ H. H. Mottern and H. L. Cole, J. Am. Chem. Soc. 61, 2701 (1939); W. W. Pigman, J. Research NBS 25, 301 (1@40) RP1325.

$508748-43-2$ 


\section{Journal of Research of the National Bureau of Standards}

of alpha-amylase (chiefiy destrogenic) obtained from B. mesentericus by extraction and salt precipitation. The preparation is standardized to a definite starch liquefying power, a mixture of sodium chloride, sodium sulfate, and phosphates being used as diluent. The preparation contains appreciable amounts of bacterial proteolytic enzymes. Optimum $\mathrm{pH}$ range, 6.5 to 8.0 ; optimal temperature range, $65^{\circ}$ to $70^{\circ} \mathrm{C}$." It dissolves practically completely in water.

Yeast Emulsin No. 1.-(Invertase solution in 10-ml sealed glass vials.) Solid substance is $0.257 \mathrm{~g}$ in $10 \mathrm{ml}$ of solution. For information on commercialinvertase preparations, see review by L. Wallerstein. ${ }^{36}$

\section{SUBSTRATES}

Sucrose.-Standard Sample No. 17, Standard Sucrose, of the National Bureau of Standards was used. This material may be purchased from this Bureau.

Inulin.-A sample of once recrystallized inulin from dahlias was recrystallized twice from hot water $\left(90^{\circ} \mathrm{C}\right)$ and dried in air. Moisture content as determined by drying to constant weight in high vacuum at $90^{\circ} \mathrm{C}$ was 7.7 percent. All weights recorded are calculated on an anhydrous basis. The optical rotation, on anhydrous basis, was $[\alpha]_{D}^{20}=-40.8$ (c, 1.2; water). In the preparation of inulin solutions, it was necessary to warm the solutions to $60^{\circ}$ to $70^{\circ} \mathrm{C}$ to bring about dissolution and then to cool them to room temperature before making them to volume. Although supersaturated, the solution remains clear for several days.

\section{BUFFER SOLUTIONS}

Two types of buffer solutions were used. In the range $\mathrm{pH} 3$ to 5.5, Walpole acetate buffers, made by mixing $0.2 M$ acetic acid and $0.2 M$ sodium acetate, were found satisfactory. For the measurements above $\mathrm{pH} 5.5$, the Clark and Lubs phosphate buffers $(0.05 M)$ were employed. The hydrogen-ion concentrations were measured with a glass electrode $\mathrm{pH}$ meter at $25^{\circ} \mathrm{C}$. Since the enzyme preparations had considerable buffering action, the $\mathrm{pH}$ values recorded should be considered as only approximate. In all instances, buffer mixtures containing emulsin were measured and found to vary not more than 0.1 from that of the recorded value for the buffer alone. Two hydrogen-ion concentrations, $\mathrm{pH}=4.5$ and 6.5 , were chosen for the analyses of enzyme activity. Most enzymes are active at one of these $\mathrm{pH}$ values, but for accurate work, the analyses should be made at the $\mathrm{pH}$ optimum, as recommended by Weidenhagen.

\section{HYDROLYSIS MEASUREMENTS}

Two methods were used. In the first, a weighed quantity of emulsin was added to $10 \mathrm{ml}$ of the substrate in undiluted buffer solution attemperated at $30^{\circ} \mathrm{C}$. At appropriate times, 1- or 2-ml samples were removed with a pipette, added to $20 \mathrm{ml}$ of copper sulfate-sodium citrate solution, and analyzed for reducing sugar by the modified Scales method. ${ }^{37}$ A more accurate procedure is applied by adding $2 \mathrm{ml}$ of enzyme solution to $8 \mathrm{ml}$ of substrate solution, both attemperated at $30^{\circ} \mathrm{C}$. The substrate concentration was always $2.375 \mathrm{~g}$ of sucrose or $1.013 \mathrm{~g}$ of inulin (anhydrous) in $50 \mathrm{ml}$ of reaction mixture. ${ }^{38}$

${ }^{36}$ L. Wallerstein, Wallerstein Lab. Comm. No. 7, p. 10 (December 1939); U. S. Patents No. 1,919,675 and $1,919,676$ (July 25, 1923)

37 H. S. Isbell, W. W. Pigman, and H. F. Frush, J. Research NBS 24, 241 (1940) RP1282.

${ }^{38}$ In future work, the inulin concentration will be changed to $1.125 \mathrm{~g}$ of inulin in $50 \mathrm{ml}$, as suggested by Weidenhagen. 
The temperatures were maintained at $30.0^{\circ} \pm 0.3^{\circ} \mathrm{C}$ during the reaction period. Glass-stoppered test tubes provided satisfactory containers, and when the reaction required more than 8 hours, $2 \mathrm{ml}$ of toluene was added to the reaction mixture. For the method of calculation, see section II, p. 162. The observed quantities of reducing sugar were corrected for the iodine consumption of enzyme and substrate blanks carried through a similar procedure and prepared as above, except that the substrate or enzyme was omitted.

A number of individuals and firms have been of great assistance in providing materials and advice in the present investigation. The writer expresses his appreciation tor the cooperation of the following persons and firms: R. F. Jackson, E. McDonald, and C. F. Snyder, of the Polarimetry Section, National Bureau of Standards; Phillip Gray, representing the Wallerstein Laboratories, New York, N. Y.; S. Laufer, representing the Schwarz Laboratories, New York, N. Y.; W. N. Given and J. A. Shellenberger, representing the Röhm \& Haas Co., Philadelphia, Pa.; C. W. Frey and W. R. Johnston, representing the Fleischmann Laboratories, New York, N. Y.; and J. J. Willaman, of the Eastern Regional Research Laboratory (United States Dept. of Agriculture).

Washington, November 27, 1942. 